Prepared in cooperation with the U.S. Fish and Wildlife Service

Differentiating Sediment Sources Using Sediment Fingerprinting Techniques, in the Sprague River Basin, South-Central Oregon

Open-File Report 2019-1120 
Cover: Eroding banks on Sprague River, south-central Oregon. Photograph by Llam Schenk, U.S. Geological Survey, May 18, 2017. 


\section{Differentiating Sediment Sources Using Sediment Fingerprinting Techniques, in the Sprague River Basin, South-Central Oregon}

By Liam N. Schenk, Tessa M. Harden, and Julia K. Kelson

Prepared in cooperation with U.S. Fish and Wildlife Service

Open-File Report 2019-1120 


\section{U.S. Department of the Interior \\ DAVID BERNHARDT, Secretary}

\section{U.S. Geological Survey James F. Reilly, Director}

U.S. Geological Survey, Reston, Virginia: 2019

For more information on the USGS-the Federal source for science about the Earth, its natural and living resources, natural hazards, and the environment-visit https://www.usgs.gov/ or call 1-888-ASK-USGS (1-888-275-8747).

For an overview of USGS information products, including maps, imagery, and publications, visit https://store.usgs.gov/.

Findings and conclusions in this report are those of the authors and do not necessarily represent the views of the U.S. Fish and Wildlife Service.

Any use of trade, firm, or product names is for descriptive purposes only and does not imply endorsement by the U.S. Government.

Although this information product, for the most part, is in the public domain, it also may contain copyrighted materials as noted in the text. Permission to reproduce copyrighted items must be secured from the copyright owner.

Suggested citation:

Schenk, L.N., Harden, T.M., and Kelson, J.K., 2019, Differentiating sediment sources using sediment fingerprinting techniques, in the Sprague River Basin, south-central Oregon: U.S. Geological Survey Open-File Report 2019-1120, 25 p., https://doi.org/10.3133/ofr20191120. 


\section{Contents}

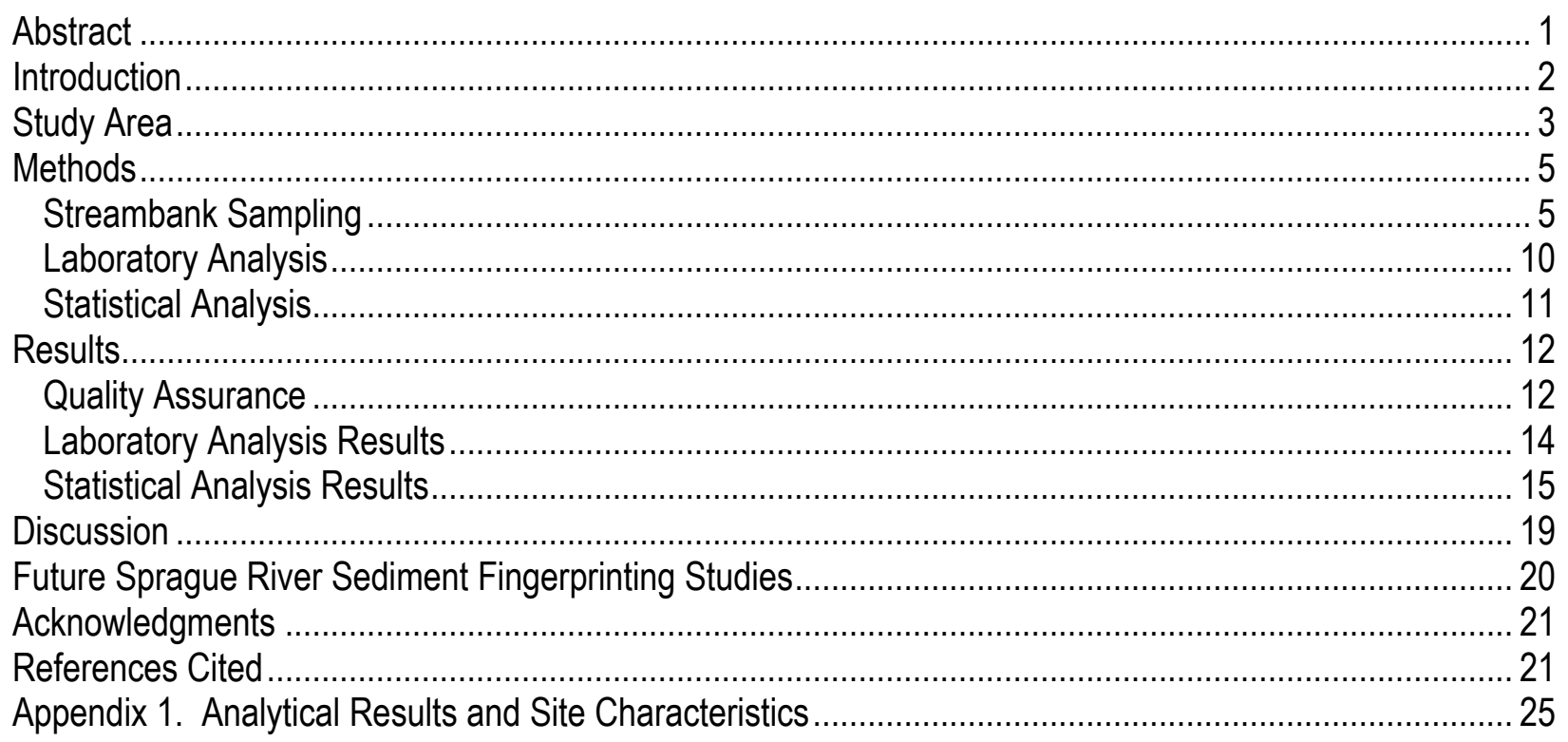

\section{Figures}

Figure 1. Map showing sampling locations, hydrology, and mapped soil units for the Sprague River Basin, south-central Oregon................................................................................................... 4 Figure 2. Photograph showing example of eroding banks and banks disturbed by cattle on the South Fork Sprague River, south-central Oregon..

Figure 3. Photograph showing example of eroding banks on the South Fork Sprague River, southcentral Oregon.

\section{Tables}

Table 1. Number of samples per source material type, soil horizon, mapped soil unit name, basin, and river reach, in the study area, Sprague River Basin, south-central Oregon ....

Table 2. Quality assurance sample descriptions and site locations, in the study area, Sprague River Basin, south-central Oregon.....

Table 3. Replicate sample results for metals and base cations (elemental analysis), in the study area, Sprague River Basin, south-central Oregon

Table 4. Replicate sample results for total carbon, total nitrogen, carbon stable isotopes, and nitrogen stable isotopes, in the study area, Sprague River Basin, south-central Oregon

Table 5. Quality assurance results of composite samples, in the study area, Sprague River Basin, south-central Oregon.

Table 6. P-value results of Lilliefors normality test done on 24 fingerprint properties, in the study area, Sprague River Basin, south-central Oregon

Table 7. P-value results of Kruskal Wallis H-test done on 24 fingerprint properties, in the study area, Sprague River Basin, south-central Orego.

Table 8. Wilks' lambda test results for select fingerprint properties by material, basin, and reach categories, in the study area, Sprague River Basin, south-central Oregon

Table 9. Reclassification of fitness test results 


\section{Conversion Factors}

U.S. customary units to International System of Units

\begin{tabular}{|c|c|c|}
\hline Multiply & By & To obtain \\
\hline \multicolumn{3}{|c|}{ Length } \\
\hline mile (mi) & 1.609 & kilometer $(\mathrm{km})$ \\
\hline \multicolumn{3}{|c|}{ International System of Units to U.S. customary units } \\
\hline Multiply & By & To obtain \\
\hline \multicolumn{3}{|c|}{ Length } \\
\hline meter $(\mathrm{m})$ & 3.281 & foot $(\mathrm{ft})$ \\
\hline \multicolumn{3}{|c|}{ Area } \\
\hline square kilometer $\left(\mathrm{km}^{2}\right)$ & 247.1 & acre \\
\hline square kilometer $\left(\mathrm{km}^{2}\right)$ & 0.3861 & square mile $\left(\mathrm{mi}^{2}\right)$ \\
\hline \multicolumn{3}{|c|}{ Mass } \\
\hline milligram (mg) & 0.00003527 & ounce, avoirdupois (oz) \\
\hline kilogram $(\mathrm{kg})$ & 2.205 & pound avoirdupois (lb) \\
\hline
\end{tabular}

\section{Datum}

Horizontal coordinate information is referenced to the North American Datum of 1983 (NAD 83).

\section{Supplemental Information}

Concentrations of chemical constituents in soils are given in milligrams per kilogram $(\mathrm{mg} / \mathrm{kg})$.

Results for measurements of stable isotopes of an element (with symbol E) in water, solids, and dissolved constituents commonly are expressed as the relative difference in the ratio of the number of the less abundant isotope (iE) to the number of the more abundant isotope of a sample with respect to a measurement standard.

\section{Abbreviations}

$\begin{array}{ll}\text { AFA } & \text { Aphanizomenon flos-aquae } \\ \mathrm{Ag} & \text { silver } \\ \mathrm{Al} & \text { aluminum } \\ \mathrm{Ar} & \text { argon } \\ \mathrm{B} & \text { boron } \\ \mathrm{Ba} & \text { barium } \\ \mathrm{Be} & \text { beryllium } \\ \mathrm{C} & \text { carbon } \\ \mathrm{Ca} & \text { calcium } \\ \mathrm{Cd} & \text { cadmium } \\ \mathrm{Co} & \text { cobalt } \\ \mathrm{Cr} & \text { chromium } \\ \mathrm{Cu} & \text { copper } \\ \mathrm{Fe} & \text { iron } \\ \mathrm{ICP}-\mathrm{AES} & \text { Inductively Coupled Plasma-Atomic Emission Spectrometry } \\ \mathrm{K} & \text { potassium } \\ \mathrm{LDA} & \text { linear discriminant analysis } \\ \mathrm{Li} & \text { lithium } \\ \mathrm{MDL} & \text { method detection limit } \\ \mathrm{Mg} & \text { magnesium } \\ \mathrm{Mn} & \text { manganese } \\ \mathrm{Mo} & \text { molybdenum } \\ \mathrm{MRL} & \text { method reporting limit } \\ \mathrm{N} & \text { Nitrogen }\end{array}$




$\begin{array}{ll}\mathrm{Na} & \text { Sodium } \\ \mathrm{NRCS} & \text { Natural Resources Conservation Service } \\ \mathrm{P} & \text { phosphorus } \\ \mathrm{QA} & \text { quality assurance } \\ \mathrm{RPD} & \text { relative percent difference } \\ \mathrm{RSIL} & \text { Reston Stable Isotope Laboratory } \\ \mathrm{Pb} & \text { lead } \\ \mathrm{Sb} & \text { antimony } \\ \mathrm{Se} & \text { selenium } \\ \mathrm{Si} & \text { silicon } \\ \text { Th } & \text { thorium } \\ \mathrm{TMDL} & \text { Total Maximum Daily Load } \\ \text { TN } & \text { Total Nitrogen } \\ \text { UKL } & \text { Upper Klamath Lake } \\ \text { USGS } & \text { U.S. Geological Survey } \\ \text { V } & \text { vanadium } \\ \text { Zn } & \text { zinc }\end{array}$


This page intentionally left blank 


\title{
Differentiating Sediment Sources Using Sediment Fingerprinting Techniques, in the Sprague River Basin, South-Central Oregon
}

\author{
By Liam N. Schenk, ${ }^{1}$ Tessa M. Harden, ${ }^{1}$ and Julia K. Kelson ${ }^{2}$
}

\begin{abstract}
Identifying sources of sediment to streams in the Sprague River Basin, in south-central Oregon, is important for restoration efforts that are focused on reducing sediment erosion and transport. Reducing sediment loads in these streams also contributes to compliance with the total maximum daily load reduction requirements for total phosphorus in this basin. In the Sprague River Basin, phosphorus occurs in surface waters in both dissolved phase and particulate phase, and particulate phosphorus is readily transported in streams on fine-grained suspended sediments, which eventually deposit in Upper Klamath Lake. The lake has seasonal blooms of cyanobacteria that require phosphorus for growth and degrade water-quality conditions, violating State water-quality standards and creating conditions that are stressful to two endangered suckers that reside in the lake. Identifying sources of sediment to the Sprague River could help inform restoration actions by determining the principal locations in the basin contributing fine sediment to the river. The U.S. Geological Survey, in cooperation with the U.S. Fish and Wildlife Service, conducted a proof-of-concept study to determine if sediment fingerprinting can differentiate sources of bank erosion by source material, basin, river reach, and soil horizon. The sediment fingerprinting approach uses properties of streambank and streambed sediment to differentiate between multiple sediment sources by determining a composite signature, or fingerprint. The composite fingerprint is established by combining fingerprint properties from laboratory results of elemental analysis, stable isotopes, and total carbon and nitrogen. The methods for differentiating sediment samples for this study include grouping bank and bed samples by basin, river reach, and soil horizon, and using non-parametric statistics to determine which fingerprint properties could be used to differentiate the sample groups. Results indicate that fingerprint properties differentiated source material, river reach, and basin, and were more successful at differentiating samples grouped by geographic location (basin and reach) compared to source material. Source material (banks, bed, levees) were differentiated with three fingerprint properties-Antimony $(\mathrm{Sb})$, copper $(\mathrm{Cu})$, and manganese $(\mathrm{Mn})$. The basin category (South Fork and main-stem Sprague River) differentiated the South Fork and main stem with stable nitrogen isotopes $\left(\delta^{15} \mathrm{~N}\right)$, aluminum $(\mathrm{Al})$, silicon $(\mathrm{Si})$, and vanadium $(\mathrm{V})$. Specific river reaches within the study area were differentiated with 11 different fingerprint properties. These results can be used
\end{abstract}

\footnotetext{
${ }^{1}$ U.S. Geological Survey, Oregon Water Science Center

${ }^{2}$ University of Washington
} 
for apportionment studies using suspended sediment samples and mixing models to determine sediment source contributions within the basin.

\section{Introduction}

The Sprague River is one of the main tributaries to Upper Klamath Lake (UKL), a hypereutrophic (nutrient-rich) lake in south-central Oregon supporting large blooms of cyanobacteria during the dry season, which typically lasts from June to October (Eldridge and others, 2012). The blooms cause poor water-quality conditions that are considered one of the contributors to survival problems for two species of suckers, Shortnose (Chasmistes brevirostris) and Lost River (Deltistes luxatus) suckers, listed as endangered under the Federal Endangered Species Act (16 U.S.C. 1531 et seq.) (U.S. Fish and Wildlife Service, 1988). The dominant cyanobacterium in the lake is the filamentous alga Aphanizomenon flos-aquae (AFA) (Wood and others, 2006). AFA is a diazotrophic cyanobacterium, meaning it can fix atmospheric nitrogen $(\mathrm{N})$, and therefore thrive when the supply of bio-available phosphorus $(\mathrm{P})$ in the lake is adequate to promote cell growth (Rouhe and Rueter, 2018). Sources of P for AFA blooms in the lake are both external (tributaries to the lake) and internal (bottom sediments in the lake) (Walker and others, 2012; Wood and others, 2014). Within a bloom cycle, most of the P that feeds the bloom is recycled from the lake sediments, but the $\mathrm{P}$ in the sediments is a legacy of antecedent external loads, so control of external P loads is a high priority for management of the lake (Schenk and others, 2016; Wherry and others, 2015).

Streams in the Upper Klamath Basin, including the Sprague River, transport suspended sediment and associated P to UKL (Schenk and others, 2016; Walker and others, 2015). Phosphate ions are easily adsorbed by the sediments, particularly those sediments containing iron and aluminum oxide minerals (Stumm and Morgan, 1981). $\mathrm{P}$ is identified as the main pollutant causing violations of Oregon water quality standards in the lake, and the Total Maximum Daily Load (TMDL) established for UKL requires a 40-percent reduction in external P loads to meet those standards, which equates to a target load of 109 metric tons per year of total $\mathrm{P}$ from external sources (Boyd and others, 2002).

Restoration efforts that reduce bank erosion to mitigate suspended sediment loads have occurred in discrete locations in the Sprague River Valley for many years, and current waterquality management plans emphasize streamside vegetation protection and enhancement to control water pollution from agricultural activities and to prevent and control soil erosion along streambanks (Oregon Department of Agriculture, 2017). These efforts have included reducing riparian disturbances from cattle grazing by fencing, converting straightened channels into meandering channels (channel realignment), and reconnecting flood plains to main-stem channels through levee setbacks and removals (Newfields River Basin Services, 2012).

One way of identifying the main sources of sediment in the basin is with sediment fingerprinting techniques (Gellis and others, 2016, 2017; Collins and others, 2017). Sediment fingerprinting is an increasingly common technique that exploits the chemical composition of sediment to determine nonpoint sources of erosion (Collins and Walling, 2002; Mukundan and others, 2012; Haddadchi and others, 2013; Koiter and others, 2013; Walling, 2013; Gellis and others, 2016). Most fingerprinting studies assume that the fingerprint properties are conservative in nature, meaning they do not change as a result of erosion and transport processes, or evolve in a predictable manner (Collins and others, 2017). However, the assumption of conservativeness represents an area of much-needed research. 
Sediment fingerprinting is only successful if the source material has unique natural tracer characteristics (hereinafter "fingerprint properties") (Chattopadhyay and others, 2016). A key first step in sediment fingerprint studies, and the main goal of this proof-of-concept study, is to identify unique combinations of fingerprint properties (chemical and isotopic) to differentiate between sediment sources. Different erosion and transport processes and sediment source types dictate which fingerprint properties will be most successful in distinguishing between sediment sources (Koiter and others, 2013). Erosion of streambank and channel material by channel incision was previously identified as the primary source of suspended sediment in the Sprague River Basin (O'Connor and others, 2015). Therefore, for this pilot study, streambanks and channel bed material primarily were sampled, and some samples also were collected from constructed levees along the stream corridor. Land use within the study area is pastureland used primarily for cattle grazing or agricultural fields of hay and alfalfa, but also includes some forested lands.

For this study, stable isotope, organic carbon (C) and N, and inorganic elemental fingerprint properties related to the geology and history of the streambank sediment were the primary focus of the laboratory analysis. These fingerprint properties allow for differentiating sediment by source material, sub-basin, stream reach and soil horizon, the chemical compositions of which may vary.

\section{Study Area}

The Sprague River drains $4,167 \mathrm{~km}^{2}$ of south-central Oregon in Lake and Klamath Counties near the California border (fig. 1). Formed by the confluence of its north and south forks in eastern Klamath County, the Sprague River is a major contributor, along with the Williamson River, of sediment, nutrients, and water to UKL. Except for the uplands near the headwaters, much of the Sprague River and its north and south forks flow through a wide alluvial valley interrupted by narrow canyon reaches. The uplands mostly are formed by upper Miocene and Pliocene basalt and basaltic andesite lava flows issued from local vents and shield volcanoes (O'Connor and others, 2015). The broad alluvial valley mostly is from volcanic and sedimentary rock sources. The main tributaries to the Sprague River are the Sycan River (drainage area 1,447 $\mathrm{km}^{2}$ ) and Trout Creek $\left(71 \mathrm{~km}^{2}\right)$ (fig. 1). A detailed geologic map of the study area can be found in O'Connor and others (2015). 

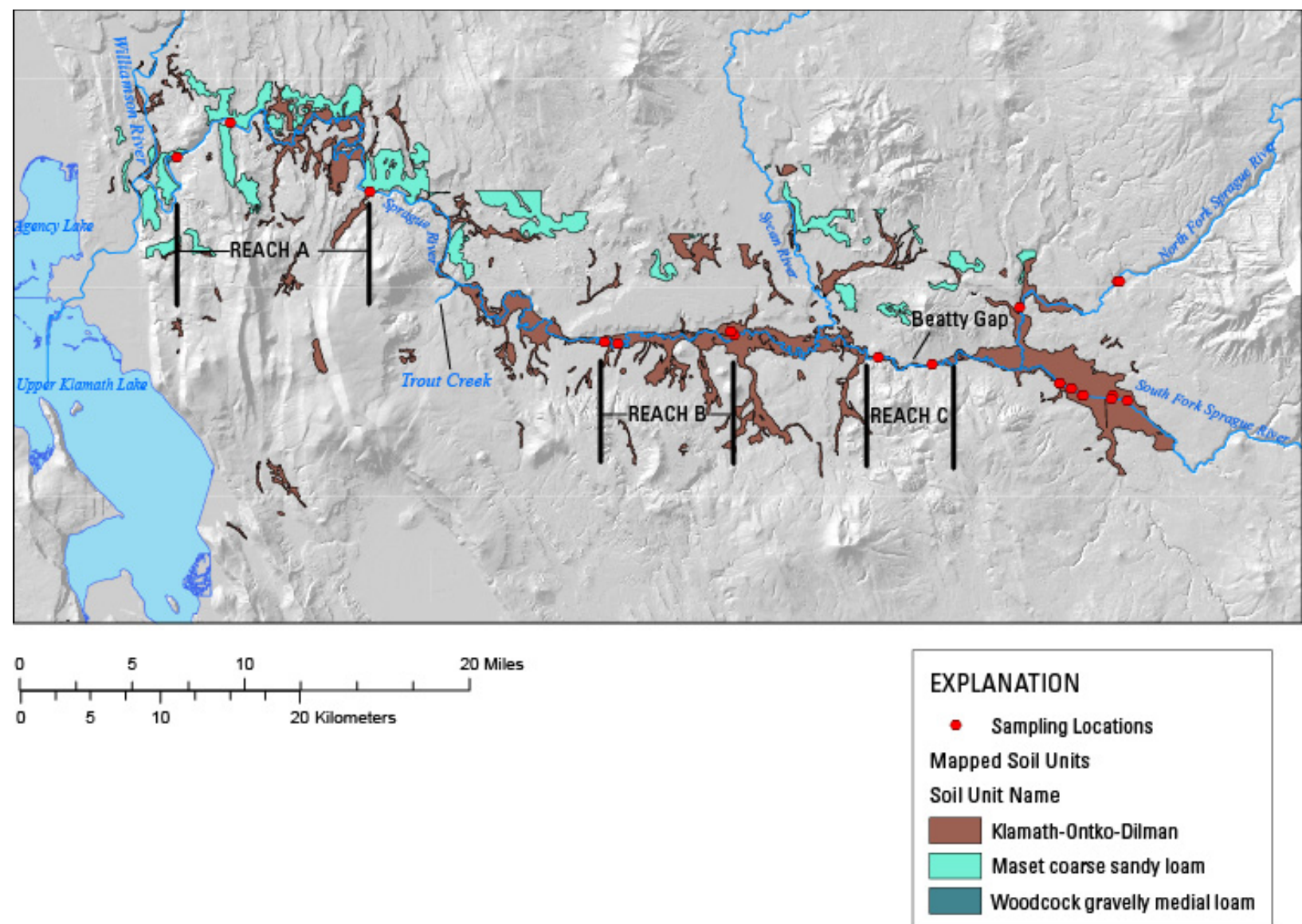

Figure 1. Map showing sampling locations, hydrology, and mapped soil units for the Sprague River Basin, south-central Oregon. Horizontal coordinate information is referenced to the North American Datum of 1983 (NAD 83).

Vegetation in the uplands of the basin consists of mixed conifer forests of mostly ponderosa and lodgepole pine. Valley bottoms are dominated by riparian shrublands, wetland vegetation, and grassland meadows. Much of the valley is used for agriculture, mainly irrigated pasture grasses and hay to support livestock. The transition zone between the cooler uplands and the warmer valley bottoms is vegetated by sagebrush and juniper.

The Natural Resources Conservation Service (NRCS) has mapped the soil units in the Sprague River Basin as silt or clay loam over layers of ashy sandy clay loam (Cahoon, 1985). Soil depth is greater than $1 \mathrm{~m}$ in most places. Soil unit 4352, or the Klamath-Ontko-Dilman complex (a poorly drained floodplain soil), is mapped exclusively in the South Fork Sprague River (SF) and the Sprague River main stem from the North Fork (NF)/SF confluence to Trout Creek (Cahoon, 1985; fig. 1), likely indicating the historic drainage conditions and vegetation. The SF probably was more of a wet meadow compared to other parts of the Sprague River because of bedrock and colluvial slope constrictions near Beatty Gap (O'Connor and others, 2015; fig. 1). The soil complex contains Klamath soil (a very dark gray and black silty clay), the Ontko soil (a black silty clay loam), and Dilman soil (a black silty clay and black silty clay loam; Cahoon, 1985). East of Beatty Gap, NRCS observed Quaternary silty diatomaceous lacustrine deposits, indicating previous inundation by water. 
Geomorphic and land-use observations, as well as suspended sediment sampling, suggest that the SF likely is a major contributor to suspended sediment loading in the Sprague River system (Graham Matthews and Associates, 2007; O'Connor and others, 2015). Currently, incision, levees, and irrigation ditches, as well as draining and leveling of floodplains, have turned the former wet-meadow complex into a straightened channel that rarely inundates its floodplains. The channel straightening and disturbance in streamside vegetation has increased erosion through channel incision and bank erosion (O'Connor and others, 2015). Channel confinement by levees, dikes, and roads often leads to erosion of channel beds (incision), which results in higher shear stress on the bed as larger flows are constrained within the banks, and can ultimately lead to deeper and faster streamflow promoting erosion of stream channels (Watson and others, 2002). The downstream reaches of the Sprague River are depositional: ${ }^{137} \mathrm{Cs}$ isotope data indicated recent sediment deposition along the floodplains downstream of the SF/NF confluence (O'Connor and others, 2015), and a sediment budget from 2004-06 showed that about 63 percent of the total suspended sediment load from the NF and SF Sprague River was measured at the basin outlet near Chiloquin (Graham Matthews and Associates, 2007). These lower reaches (downstream of the NF/SF confluence) have been modified by levees, irrigation ditches, and diversion dams; however, they have retained a high sinuosity and connectivity to the floodplain compared to the SF.

\section{Methods}

\section{Streambank Sampling}

Because the main source of suspended sediment in the Sprague River was previously determined to be bank erosion (O'Connor and others, 2015), this study did not target any additional source areas such as agricultural fields, ditches, or forested land. Additional observations from a field reconnaissance (June 2017) also indicated that most of the sediment erosion was occurring along the channel banks for three reasons: (1) minimal upland erosion or rilling was observed; (2) thick grass and vegetation upland could deter erosion of those sediments; and (3) many eroding banks greater than $1 \mathrm{~m}$ high were observed, composed of only fine-grained sediment (figs. 2 and 3). As a result, our sampling efforts were focused on collecting sediment from the river banks and bed material in the active channel. Artificial levees also were sampled as another possible sediment source that could be distinct from sediment that is weathering naturally in place. This sampling approach is a departure from random sampling designs of varied target and source areas that are well connected to the river (Davis and Fox, 2009; Du and Walling, 2017). 


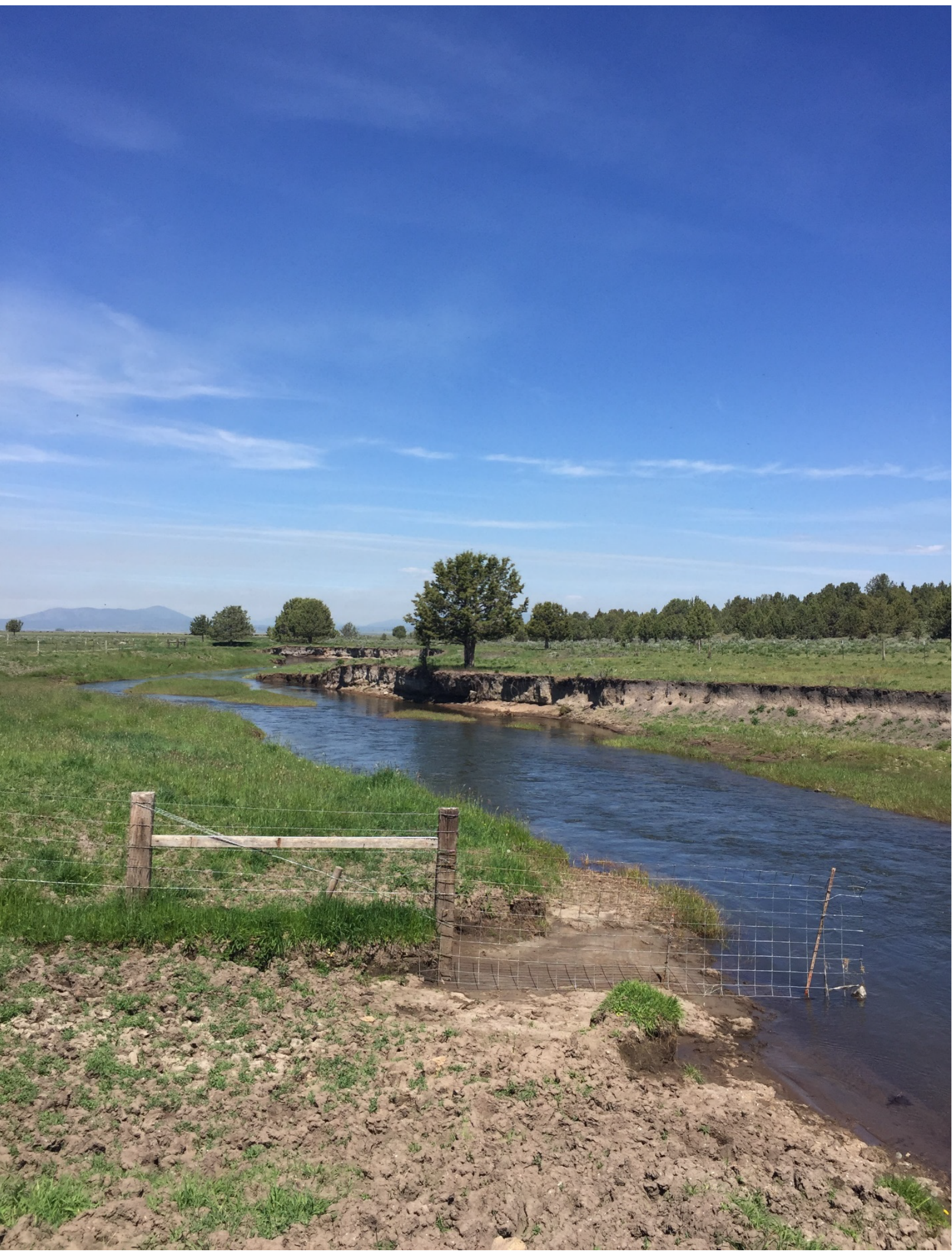

Figure 2. Photograph showing example of eroding banks and banks disturbed by cattle on the South Fork Sprague River, south-central Oregon. Photograph by Liam Schenk, U.S. Geological Survey, May 23, 2017. 


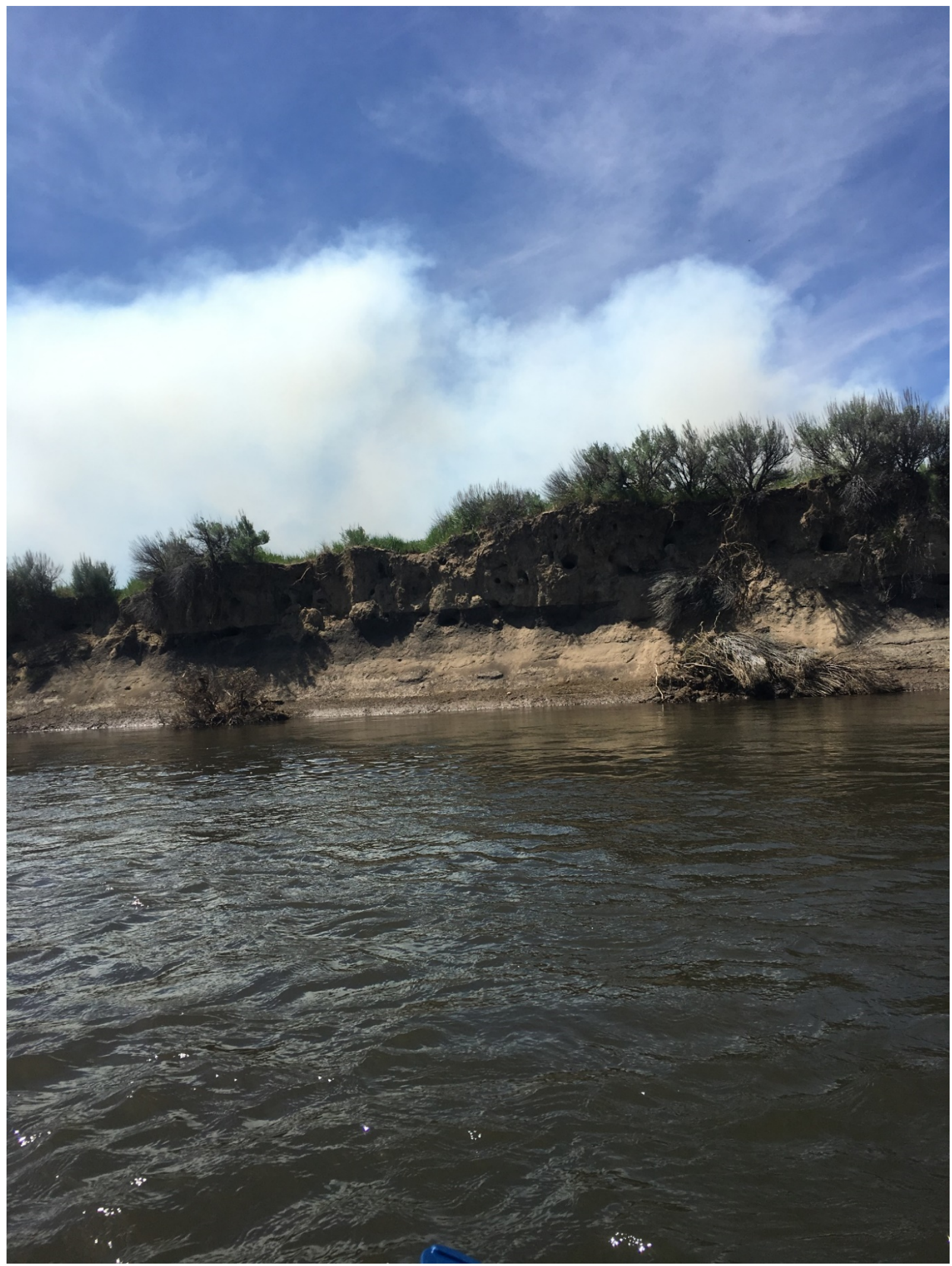

Figure 3. Photograph showing example of eroding banks on the South Fork Sprague River, south-central Oregon. Photograph by Liam Schenk, U.S. Geological Survey, May 24, 2017. 
Sample locations were selected along the NF, SF, and main-stem river reaches, based mainly on soil type in those reaches and accessibility because most of the Sprague River channel is on private land. Sites also were chosen to represent a large spatial area of the basin. Most samples were collected in the Klamath-Ontko-Dilman mapped soil unit, which is mapped almost exclusively in the NF, SF, and main-stem Sprague River from the headwaters to Trout Creek (fig. 1). The three sites closest to the Sprague-Williamson River confluence represented mapped soil units Maset coarse sandy loam and the Woodcock gravelly medial loam. Three samples in the upper NF Sprague River were collected in an unmapped soil unit (fig. 1). At each site, soil material was categorized into three types_-bank, bed, and levee (table 1). Bank samples were those that were collected from river banks with distinct soil horizons or visible flood plain stratigraphy and composed most of the samples collected. Bed samples were collected within the channel and represented sediment that was eroded, transported by the river, and deposited in the streambed. Levee samples were collected from the banks of known constructed levees and were assumed to be composed of fill material that could be a source of sediment to the river.

At each sampling location, the height of the exposure from the top of the eroding surface to the water surface was measured and the stratigraphy was briefly described. Qualitative descriptions of vegetative cover and material including soil texture, cohesiveness, and color were recorded at each site (appendix 1). At sites where different soil horizons were identified, each horizon was sub-sampled for analysis. Soil samples were collected in a glass bowl and mixed with a large plastic spoon from three or four locations within each soil horizon along a 10-m section of the bank. Samples were then transferred to a glass jar for metals and base cation (elemental) concentration analysis or to aluminum foil and plastic sample bags for stable isotope analysis. The stable isotope laboratory also analyzed the samples for total carbon (TC) and total nitrogen $(\mathrm{TN})$. At some locations, all the soil horizons were composited into one sample at a single location on the riverbank to compare concentrations of fingerprint properties from individual soil horizons to the composite sample. A total of 62 samples from 21 sites plus 4 samples for quality assurance (QA) were collected for analysis of metals and base cations, and stable isotopes (table 2). As a result, the total number of samples analyzed by the laboratories for this study was 66, including QA samples (appendix 1). The four QA samples and two other samples did not have equal number of results for all fingerprint properties because some were sent to either RTI Laboratory (a contract laboratory for the U.S. Geological Survey [USGS], Livonia, Michigan) for elemental concentration analysis or to the USGS Reston Stable Isotope Laboratory (RSIL) in Reston, Virginia, and, therefore, did not have the same number of results per sample. As a result, these samples were omitted from the dataset prior to statistical analysis, resulting in a total of 60 samples for the statistics used to differentiate sediment sources. 
Table 1. Number of samples per source material type, soil horizon, mapped soil unit name, basin, and river reach, in the study area, Sprague River Basin, south-central Oregon.

\begin{tabular}{lcc}
\hline \multicolumn{1}{c}{ Source type } & Number of samples & Number of sites \\
\hline Bank & Material & \\
Bed & 42 & 12 \\
Levee & 14 & 5 \\
\hline \multicolumn{2}{c}{ Soil horizon } & 4 \\
\hline A horizon & 15 & 12 \\
B horizon & 17 & 13 \\
\hline \multicolumn{4}{c}{ Mapped soil unit name } \\
\hline Klamath-Ontko-Dilman & 55 & 17 \\
Maset coarse sandy loam & 7 & 2 \\
Woodcock gravelly medial loam & 1 & 1 \\
Unmapped & 3 & 1 \\
\hline \multicolumn{2}{c}{ Basin } & 9 \\
\hline South Fork Sprague & 30 & 2 \\
North Fork Sprague & 7 & 10 \\
Main-stem Sprague & 29 & 9 \\
\hline & 30 & 2 \\
\hline South Fork & 7 & 3 \\
North Fork & 8 & 5 \\
Main Stem A & 16 & 2 \\
Main Stem B & 5 & \\
Main Stem C & & \\
\hline
\end{tabular}


Table 2. Quality assurance sample descriptions and site locations, in the study area, Sprague River Basin, south-central Oregon.

[Abbreviations: ICP-AES, Inductively Coupled Plasma-Atomic Emission Spectrometry; ID, identification number; $\mathrm{RM}$, river mile]

\begin{tabular}{cll}
\hline \multicolumn{1}{c}{ Site ID } & \multicolumn{1}{c}{ Site name } & \multicolumn{1}{c}{ Sample description } \\
\hline 422513121032600 & \multicolumn{1}{c}{ Split samples for metals and base cations using ICP-AES } & \\
422756121214400 & SOUTH FORK SPRAGUE RIVER NEAR RM 3.5 & Bank (ash layer) \\
423337121402800 & SPRAGUE RIVER NEAR RM 62.5 & A horizon \\
\hline & SPRAGUE RIVER NEAR RM 29.5 & B horizon \\
\hline 422513121032600 & Split samples for stable isotopes, total carbon, and total nitrogen & \\
422541121043700 & SOUTH FORK SPRAGUE RIVER NEAR RM 3.5 & B horizon \\
422630121111600 & SOUTH FORK SPRAGUE RIVER NEAR RM 2.5 & Levee \\
\hline & Composite samples for metals and base cations using ICP-AES & Composite \\
\hline 422459121010600 & SOUTH FORK SPRAGUE RIVER NEAR RM 5.5 & Composite \\
422541121043700 & SOUTH FORK SPRAGUE RIVER NEAR RM 2.5 & Composite \\
422630121111600 & SPRAGUE RIVER NEAR RM 77.5 & Composite \\
422740121281900 & SPRAGUE RIVER NEAR RM 52.5 & Composite \\
\hline
\end{tabular}

\section{Laboratory Analysis}

Samples analyzed for elemental concentration by Inductively Coupled Plasma-Atomic Emission Spectrometry (ICP-AES) were wet sieved through a $63-\mu \mathrm{m}$ synthetic (nonmetallic) sieve prior to laboratory analysis. Samples analyzed for $\mathrm{C}$ and $\mathrm{N}$ isotopes were wet sieved through a $63-\mu \mathrm{m}$ brass sieve. The size fraction less than $63 \mu \mathrm{m}$ represents most suspended sediment (about 90 percent) that is transported in the water column during moderate flow events in the Sprague River, as evidenced by suspended-sediment samples collected by the U.S. Geological Survey (USGS) (Schenk and others, 2016).

Sediment samples for elemental concentrations were analyzed by RTI Laboratories for metals and base cations using U.S. Environmental Protection Agency method 6010C, ICP-AES (U. S. Environmental Protection Agency, 2000). Elemental concentrations of calcium (Ca), magnesium $(\mathrm{Mg})$, potassium $(\mathrm{K})$, sodium $(\mathrm{Na})$, silicon $(\mathrm{Si})$, aluminum $(\mathrm{Al})$, barium $(\mathrm{Ba})$, beryllium $(\mathrm{Be})$, cadmium $(\mathrm{Cd})$, chromium $(\mathrm{Cr})$, cobalt $(\mathrm{Co})$, copper $(\mathrm{Cu})$, iron $(\mathrm{Fe})$, lead $(\mathrm{Pb})$, lithium (Li), manganese (Mn), molybdenum (Mo), nickel (Ni), silver (Ag), thorium (Th), vanadium $(\mathrm{V})$, zinc $(\mathrm{Zn})$, antimony $(\mathrm{Sb})$, argon $(\mathrm{Ar})$, boron $(\mathrm{B})$, and selenium $(\mathrm{Se})$ were determined following this method. Total phosphorus as $\mathrm{P}$ was analyzed using method A4500 PF(American Public Health Association, 2017). A second set of samples was sent to the RSIL for analysis of carbon stable isotopes $\left(\delta^{13} \mathrm{C}\right)$, nitrogen stable isotopes $\left(\delta^{15} \mathrm{~N}\right)$ following methods in Résvész and others (2012). TC and TN concentrations were provided by the RSIL and are produced by mass spectrometer as the by-products of the isotope analysis. The laboratory obtains a mass amount of $\mathrm{C}$ and $\mathrm{N}$ as part of their isotopic analysis by comparing environmental sample results to reference standards, and then divides the elemental mass by total mass of the sample to obtain a concentration reported in milligrams per kilogram. The RSIL does not have a standard 
operating procedure (SOP) for $\mathrm{C}$ and $\mathrm{N}$ analysis because it is part of the analytical sequences for stable isotopes. Laboratory uncertainty for $\delta^{13} \mathrm{C}$ and $\delta^{15} \mathrm{~N}$ analyzed at the RSIL is plus or minus 0.50 per mil (\%o). Reporting levels for samples analyzed at RTI Laboratories are shown in appendix 1.

\section{Statistical Analysis}

To identify unique fingerprint properties that could be used to differentiate various sediment sources, we used a multi-step statistical procedure. All statistical analyses were done with R programming language (R Core Team, 2017) using the MASS (Venables and Ripley, 2002) and klaR (Weihs and others, 2005) packages. Before statistical tests were done, the datasets were tested for normality using the Lilliefors test, an adaptation of the KolmogorovSmirnov test (Collins and others, 2012). The Lilliefors test was done using the nortest R package (Gross and Ligges, 2015).

After evaluating the normality of the dataset, the differentiation of sediment sources was evaluated using the Kruskal-Wallis $\mathrm{H}$ test combined with a multivariate-discriminant analysis and a linear discriminant analysis (LDA). The sources were categorized into multiple groups based on source material (bank, bed, levee), basin (main stem, NF, and SF), reaches (A, B, C, NF and SF; fig. 1) and soil horizon (A and B; table 1). The main-stem Sprague River was divided into 3 reach categories (A, B, and C). Splitting up the main stem into three separate reaches allows for investigating differences of sediment signatures in smaller reaches of the larger main stem, which is a spatial scale more applicable to restoration efforts in the basin. Reach A included samples collected from the Maset coarse sandy loam and the Woodcock gravelly medial loam soil units at the most downstream sites on the Sprague River. Reach B included samples collected from the Klamath-Ontko-Dilman complex in the Sprague River Valley downstream of the Sprague-Sycan confluence; and reach $\mathrm{C}$ included sites and samples in the Sprague River between the NF and Sycan confluences, also within the Klamath-Ontko-Dilman complex. The NF and SF reaches are identical to the NF and SF basin categories. Statistics evaluating samples collected from distinct mapped soil units also were evaluated, but most of the samples were collected from the Klamath-Ontko-Dilman complex, which would result in comparing a large group size $(n=52)$ to much smaller group sizes for the three other soil unit samples $(n=7,3$, and 1). Therefore, statistical tests were not done on the soil unit groups to avoid reporting spurious results.

The first step of the statistical process used the Kruskal-Wallis H-test to determine if there are statistically significant differences between the fingerprint properties for each source category by comparing concentrations of elements in the samples (Collins and Walling, 2002). The null hypothesis is that concentrations of specific elements show no significant differences between source category. A rejection of the null hypothesis, or a statistically significant output, means that there is a difference in concentrations. This method does not confirm which sourcepair combination is significantly different; it only confirms that a difference exists between concentrations in at least two sources.

The second step involved multivariate-discriminant analysis to determine the optimal combination of fingerprint properties that passed the Kruskal-Wallis H-test that can be used to differentiate the sources in each category. This was a two-stage process. The first stage was stepwise forward variable selection based on the minimization of the Wilks' Lambda. The Wilks' Lambda test is a direct measure of the proportion of variance in the combination of fingerprint properties that is unaccounted for by the source classification. Stage two was an 
LDA, which tests how well the combination of fingerprint properties (composite fingerprint) predicts or classifies the sources, also called the re-classify fitness test. These fingerprint properties are interpreted as the optimum composite fingerprint that discriminate between each source category.

\section{Results}

\section{Quality Assurance}

Quality assurance of sample results was assessed in two different ways. First, replicate samples were collected to test the variance of the analytical results within the laboratory. The replicate samples, taken from samples collected from individual soil horizons, were separated after the samples were wet sieved and prior to sample shipment to the laboratory. Replicate samples for elemental analysis (RTI Laboratories) and TC, TN, and stable isotope analysis (RSIL) were collected from the sites shown in table 2. Results from those comparisons are shown in tables 3 and 4, respectively. Relative percent difference (RPD) for elemental analysis for the primary and replicate samples ranged from 0 percent to 91 percent. The highest RPDs occurred in Ar and Ag results that were at low concentrations. For the remaining samples, the RPDs were less than 20 percent except for one P sample at Sprague River near RM 29.5, which had an RPD of 35 percent, and one Na sample at Sprague River near RM 62.5, which had an RPD of 22 percent. RPDs for replicate samples of TC and TN ranged from 0 to 21 percent. RPDs for carbon stable isotope results ranged from 0.73 to 1.19 percent, and nitrogen stable isotope results ranged from 2 to 4 percent. The difference between all stable isotope replicate samples was within the laboratory uncertainty for isotopic results, which was reported as 0.5 per mil for a 2-sigma confidence interval.

Table 3. Replicate sample results for metals and base cations (elemental analysis), in the study area, Sprague River Basin, south-central Oregon.

Table 3 is an Excel $^{\circledR}$ file available for download at https://doi.org/10.3133/ofr20191120. 
Table 4. Replicate sample results for total carbon, total nitrogen, carbon stable isotopes, and nitrogen stable isotopes, in the study area, Sprague River Basin, south-central Oregon.

[Sample type: RPD, relative percent difference. TC: total carbon. TN: total nitrogen. $\boldsymbol{\delta}^{\mathbf{1 3}} \mathbf{C}$ : carbon stable isotopes. $\boldsymbol{\delta}^{\mathbf{1 5}} \mathbf{N}$ : nitrogen stable isotopes. Abbreviations: ID, identification number; $\mathrm{mg} / \mathrm{kg}$, milligram per kilogram; \%, percent; \%o, per mil]

\begin{tabular}{|c|c|c|c|c|c|c|c|c|c|}
\hline Station ID & Station name & Date & Time & Source type & $\begin{array}{c}\text { Sample } \\
\text { type }\end{array}$ & $\begin{array}{c}\mathrm{TC} \\
(\mathrm{mg} / \mathrm{kg})\end{array}$ & $\begin{array}{c}\mathrm{TN} \\
(\mathrm{mg} / \mathrm{kg})\end{array}$ & $\begin{array}{l}\delta^{13} \mathrm{C} \\
(\%)\end{array}$ & $\begin{array}{l}\delta^{15 N} \\
(\%)\end{array}$ \\
\hline 422513121032600 & $\begin{array}{l}\text { SOUTH FORK SPRAGUE } \\
\text { RIVER NEAR RM } 3.5\end{array}$ & $07-10-17$ & 1503 & B horizon & Primary & 18,000 & 1,500 & -27.92 & 2.65 \\
\hline \multirow[t]{3}{*}{422513121032600} & $\begin{array}{l}\text { SOUTH FORK SPRAGUE } \\
\text { RIVER NEAR RM } 3.5\end{array}$ & $07-10-17$ & 1510 & B horizon & Split & 18,000 & 1,500 & -27.59 & 2.77 \\
\hline & & & & & Difference & 0 & 0 & 0.33 & 0.12 \\
\hline & & & & & RPD & $0 \%$ & $0 \%$ & $1.19 \%$ & $4 \%$ \\
\hline 422541121043700 & $\begin{array}{l}\text { SOUTH FORK SPRAGUE } \\
\text { RIVER NEAR RM } 2.5\end{array}$ & $07-10-17$ & 1201 & Levee & Primary & 17,000 & 1,700 & -27.35 & 3.57 \\
\hline \multirow[t]{3}{*}{422541121043700} & $\begin{array}{l}\text { SOUTH FORK SPRAGUE } \\
\text { RIVER NEAR RM } 2.5\end{array}$ & $07-10-17$ & 1210 & Levee & Split & 21,000 & 1,900 & -27.15 & 3.72 \\
\hline & & & & & Difference & $-4,000$ & -200 & 0.2 & 0.15 \\
\hline & & & & & RPD & $21 \%$ & $11 \%$ & $0.73 \%$ & $4 \%$ \\
\hline 422630121111600 & $\begin{array}{l}\text { SPRAGUE RIVER } \\
\text { NEAR RM } 77.5\end{array}$ & $07-11-17$ & 1432 & Composite & Primary & 12,000 & 1,000 & -26.69 & 5.64 \\
\hline \multirow[t]{3}{*}{422630121111600} & $\begin{array}{l}\text { SPRAGUE RIVER } \\
\text { NEAR RM } 77.5\end{array}$ & $07-11-17$ & 1435 & Composite & Split & 11,000 & 1,000 & -26.41 & 5.52 \\
\hline & & & & & Difference & 1,000 & 0 & 0.28 & 0.12 \\
\hline & & & & & RPD & $9 \%$ & $0 \%$ & $1.05 \%$ & $2 \%$ \\
\hline
\end{tabular}


The second QA method compared composite samples to mathematical composites of individual soil horizons collected at some sample locations following methods by the British Columbia Ministry of Environment (2001). The purpose of comparing the composite samples to the mathematical composite of the individual horizons was to measure the variability of individual samples within the composite sample. This analysis determines if collecting composite samples of various soil horizons at a given location is an appropriate representation of the soil concentrations at a given site. Measurement of the variability of samples within a composite was achieved by calculating the within-composite standard deviation using equation 1. The average of the discrete samples within the composite also was calculated and compared to the composite concentration, and an RPD also was calculated. Within-composite standard deviations were not calculated for discrete results that were left-censored (less than a specified value), or for stable isotope results.

$$
s=\sqrt{\frac{1}{N} \sum_{j=1}^{N}\left[D_{i, j}-C_{i}\right]^{2}}
$$

where

$s$ is the standard deviation,

$N$ is the number of discrete samples within the composite,

$D$ is the analytical value of the $j$ th discrete sample in the $i$ th composite, and

$C$ is the analytical value of the composite analysis.

Results of within-composite standard deviations for each fingerprint property are shown in table 5. Within-composite standard deviations were compared to the overall standard deviation in the dataset for each fingerprint property, resulting in 85 percent of the within-composite standard deviations being less than the overall standard deviation in the dataset for individual fingerprint properties. RPDs of the composite concentration compared to the average of discrete concentrations in a sample ranged from 0 to 88 percent, with higher RPDs reported for lowconcentration samples (table 5). RPD and within-composite standard deviation results were variable at different sites for the same fingerprint property, suggesting that the compositing technique in the field either was not consistent at each site or that sample compositing may not be the best method for determining fingerprinting properties by soil horizon at a given sample location. Of the 60 samples used in the data analysis, 4 samples were composite samples.

Table 5. Quality assurance results of composite samples, in the study area, Sprague River Basin, southcentral Oregon.

Table 5 is an Excel $^{\circledR}$ file available for download at https://doi.org/10.3133/ofr20191120.

\section{Laboratory Analysis Results}

Concentrations of 31 fingerprint properties (29 for elemental analysis and 2 for stable isotope analysis) were determined for each sample. Concentrations of 7 elements $(\mathrm{B}, \mathrm{Cd}, \mathrm{Mo}$, $\mathrm{Ag}$, Th, Ar, and Se) were routinely at or below the ICP-AES detection limit. The method reporting limit (MRL) for these and all other analytes varied based on dilution factors necessary to conduct the analyses. For example, the concentrations of B for the four samples at site North Fork near RM 4 were reported as 2 , less than $(<) 30,<30$, and $<31 \mathrm{mg} / \mathrm{kg}$. The method detection 
limit (MDL) for B is $0.43 \mathrm{mg} / \mathrm{kg}$, and the MRL is about $6 \mathrm{mg} / \mathrm{kg}$. If the sample did not require dilution, the concentration of B between the MDL and the MRL could be reported without being left-censored (less than) but is considered an estimated value, as is the case for the result of 2 $\mathrm{mg} / \mathrm{kg}$ (estimated results were retained for statistical analysis). If the sample did require dilution, the factor by which the sample was diluted elevated the MRL, resulting in a range of MRL values reported by the laboratory for each analyte (appendix 1). For the example case of the samples from the "North Fork near RM 4" site, some samples analyzed for B required a $5 \times$ dilution, which elevated the MRL to $30 \mathrm{mg} / \mathrm{kg}$, and resulted in a left-censored result $(<30$ $\mathrm{mg} / \mathrm{kg}$ ). The seven elements (analytes) listed above whose concentrations decreased below the MRL, or were left-censored, were not used in the statistical procedure described in section, "Statistical Analysis Results," resulting in 24 fingerprint properties used in the statistical analysis. Although methods are available to glean information from laboratory results when they decrease below an MRL, the use of those methods is not advantageous for the objectives of statistical procedures used in this study.

\section{Statistical Analysis Results}

The results of the Lilliefors normality test showed that 72 percent of the fingerprint properties failed the test $(\mathrm{p}>0.05)$, confirming that the data were not normally distributed (table 6). Thus, non-parametric Kruskal-Wallis H-tests were deemed appropriate for analyzing the dataset for step 1 of the statistical analysis.

The results of the Kruskal-Wallis H-test for differentiating between source types in each category are presented in table 7 . This test showed that 11-21 of the 24 fingerprint properties had statistically significant results $(\mathrm{p}<0.05)$ for material, basin, and reach, and could be used to distinguish samples within these three categories. For the basin category, only the SF (30 samples) and main stem (29 samples) were tested owing to the disproportionately small number of samples collected in the NF (7 samples). The following fingerprint properties could be used to distinguish between samples in the material, basin, and reach source categories: $\mathrm{Ca}, \mathrm{C}, \mathrm{TN}, \mathrm{P}$, $\mathrm{Be}, \mathrm{Ni}, \mathrm{V}, \delta^{13} \mathrm{C}$, and $\delta^{15} \mathrm{~N}$.

Five fingerprint properties $(\mathrm{Ca}, \mathrm{C}, \mathrm{TN}, \mathrm{P}$, and $\mathrm{Sb})$ could be used to distinguish between samples within the soil horizon category. The significant result for $\mathrm{P}$ for the soil horizon category likely was the result of one outlier value with a high $\mathrm{P}$ concentration $(460 \mathrm{mg} / \mathrm{kg})$ from an A horizon sample at one of the SF sites (South Fork Sprague River near RM 3.5). The distribution of P results from the rest of the samples were in the range of $20-180 \mathrm{mg} / \mathrm{kg}$ for the A and B horizons. In this study, $\mathrm{Mg}$ and $\mathrm{Cr}$ were the weakest fingerprint properties and could not be used to distinguish between fingerprint properties in any category. 
Table 6. P-value results of Lilliefors normality test done on 24 fingerprint properties, in the study area, Sprague River Basin, south-central Oregon.

[Bold values indicate a statistically significant result. Fingerprint property: $\mathrm{Ca}$, calcium; $\mathrm{Mg}$, magnesium; $\mathrm{K}$, potassium; $\mathrm{Na}$, sodium; C, carbon; $\mathrm{Si}$, silicon; TN, total nitrogen; $\mathrm{P}$, phosphorus; $\mathrm{Al}$, aluminum, $\mathrm{Ba}$, barium; $\mathrm{Be}$, beryllium; $\mathrm{Cr}$, chromium; $\mathrm{Co}$, cobalt; $\mathrm{Cu}$, copper; $\mathrm{Fe}$, iron; $\mathrm{Pb}$, lead; Li, lithium; $\mathrm{Mn}$, manganese; Ni, nickel; $\mathrm{V}$, vanadium; $\mathrm{Zn}$, zinc; $\mathrm{Sb}$, antimony; $\delta^{13} \mathrm{C}$, carbon stable isotopes; $\delta^{15} \mathrm{~N}$, nitrogen stable isotopes.

Abbreviation: $n$, sample size]

\begin{tabular}{lcccccccc}
\hline $\begin{array}{c}\text { Fingerprint } \\
\text { property }\end{array}$ & $\begin{array}{c}\text { Natural } \\
(\mathbf{n}=38)\end{array}$ & $\begin{array}{c}\text { Fluvial } \\
(\mathbf{n}=14)\end{array}$ & $\begin{array}{c}\text { Levee } \\
(\mathbf{n}=10)\end{array}$ & $\begin{array}{c}\text { Main stem } \\
(\mathbf{n}=\mathbf{2 7})\end{array}$ & $\begin{array}{c}\text { North Fork } \\
(\mathbf{n}=7)\end{array}$ & $\begin{array}{c}\text { South Fork } \\
(\mathbf{n}=\mathbf{2 7})\end{array}$ & $\begin{array}{c}\text { A horizon } \\
(\mathbf{n}=15)\end{array}$ & $\begin{array}{c}\text { B horizon } \\
(\mathbf{n}=17)\end{array}$ \\
\hline $\mathrm{Ca}$ & 0.639 & 0.052 & 0.318 & 0.818 & 0.749 & 0.218 & 0.848 & 0.458 \\
$\mathrm{Mg}$ & 0.311 & $\mathbf{0 . 0 4 9}$ & 0.158 & $\mathbf{0 . 0 3 5}$ & 0.730 & 0.591 & 0.511 & 0.591 \\
$\mathrm{~K}$ & 0.075 & 0.140 & 0.425 & 0.281 & 0.242 & $\mathbf{0 . 0 4 2}$ & 0.552 & 0.131 \\
$\mathrm{Na}$ & 0.169 & 0.719 & $\mathbf{0 . 0 2 3}$ & $\mathbf{0 . 0 0 4}$ & 0.809 & $\mathbf{0 . 0 0 0}$ & $\mathbf{0 . 0 0 0}$ & 0.633 \\
$\mathrm{C}$ & $\mathbf{0 . 0 1 0}$ & 0.237 & 0.906 & 0.579 & 0.426 & 0.373 & 0.345 & $\mathbf{0 . 0 0 1}$ \\
$\mathrm{Si}$ & $\mathbf{0 . 0 0 1}$ & 0.653 & 0.789 & $\mathbf{0 . 0 0 0}$ & 0.399 & 0.110 & 0.062 & $\mathbf{0 . 0 3 0}$ \\
$\mathrm{TN}$ & $\mathbf{0 . 0 0 1}$ & 0.745 & 0.114 & 0.099 & 0.428 & $\mathbf{0 . 0 4 3}$ & $\mathbf{0 . 0 3 4}$ & $\mathbf{0 . 0 0 0}$ \\
$\mathrm{P}$ & $\mathbf{0 . 0 0 0}$ & 0.179 & 0.485 & 0.082 & $\mathbf{0 . 0 1 6}$ & $\mathbf{0 . 0 0 4}$ & 0.005 & 0.052 \\
$\mathrm{Al}$ & 0.118 & 0.750 & 0.215 & 0.072 & 0.489 & 0.094 & 0.055 & 0.726 \\
$\mathrm{Ba}$ & 0.011 & 0.221 & $\mathbf{0 . 0 1 5}$ & 0.075 & $\mathbf{0 . 0 3 7}$ & 0.146 & 0.161 & $\mathbf{0 . 0 0 6}$ \\
$\mathrm{Be}$ & 0.151 & 0.811 & 0.064 & $\mathbf{0 . 0 1 6}$ & 0.428 & 0.362 & $\mathbf{0 . 0 3 8}$ & 0.577 \\
$\mathrm{Cr}$ & 0.160 & 0.330 & 0.831 & 0.478 & 0.333 & 0.906 & 0.102 & 0.218 \\
$\mathrm{Co}$ & 0.079 & 0.431 & 0.332 & 0.179 & 0.944 & $\mathbf{0 . 0 0 0}$ & 0.874 & $\mathbf{0 . 0 0 0}$ \\
$\mathrm{Cu}$ & $\mathbf{0 . 0 0 3}$ & 0.490 & 0.403 & $\mathbf{0 . 0 2 0}$ & 0.521 & 0.075 & $\mathbf{0 . 0 0 3}$ & 0.219 \\
$\mathrm{Fe}$ & 0.167 & 0.179 & 0.246 & 0.491 & 0.428 & 0.392 & 0.553 & 0.506 \\
$\mathrm{~Pb}$ & 0.058 & 0.586 & 0.556 & $\mathbf{0 . 0 4 4}$ & 0.544 & 0.687 & 0.267 & 0.168 \\
$\mathrm{Li}$ & $\mathbf{0 . 0 0 0}$ & 0.492 & 0.492 & $\mathbf{0 . 0 0 8}$ & 0.171 & $\mathbf{0 . 0 4 3}$ & $\mathbf{0 . 0 0 0}$ & 0.270 \\
$\mathrm{Mn}$ & $\mathbf{0 . 0 0 2}$ & 0.116 & 0.657 & 0.273 & $\mathbf{0 . 0 2 7}$ & $\mathbf{0 . 0 0 0}$ & 0.506 & $\mathbf{0 . 0 1 9}$ \\
$\mathrm{Ni}$ & 0.335 & 0.828 & 0.277 & 0.290 & 0.843 & 0.265 & 0.132 & $\mathbf{0 . 0 1 9}$ \\
$\mathrm{V}$ & $\mathbf{0 . 0 1 4}$ & 0.553 & $\mathbf{0 . 0 4 7}$ & $\mathbf{0 . 0 3 7}$ & 0.723 & 0.115 & $\mathbf{0 . 0 0 4}$ & 0.719 \\
$\mathrm{Zn}$ & 0.140 & 0.204 & $\mathbf{0 . 0 1 1}$ & 0.255 & 0.379 & $\mathbf{0 . 0 1 2}$ & 0.776 & $\mathbf{0 . 0 0 9}$ \\
$\mathrm{Sb}$ & 0.076 & 0.263 & 0.384 & 0.254 & 0.832 & $\mathbf{0 . 0 0 0}$ & 0.949 & $\mathbf{0 . 0 0 0}$ \\
$\delta^{13} \mathrm{C}$ & $\mathbf{0 . 0 3 7}$ & 0.584 & 0.504 & $\mathbf{0 . 0 0 1}$ & 0.369 & 0.630 & $\mathbf{0 . 0 1 4}$ & 0.124 \\
$\delta^{15} \mathrm{~N}$ & 0.794 & 0.600 & $\mathbf{0 . 0 4 0}$ & $\mathbf{0 . 0 2 9}$ & 0.577 & 0.822 & 0.374 & 0.321 \\
\hline & & & & & & & &
\end{tabular}


Table 7. P-value results of Kruskal Wallis H-test done on 24 fingerprint properties, in the study area, Sprague River Basin, south-central Oregon.

[Bold values indicate a statistically significant result. Fingerprint property: $\mathrm{Ca}$, calcium; $\mathrm{Mg}$, magnesium; $\mathrm{K}$, potassium; Na, sodium; C, carbon; Si, silicon; TN, total nitrogen; P, phosphorus; Al, aluminum; Ba, barium; $\mathrm{Be}$, beryllium; Cr, chromium; Co, cobalt; $\mathrm{Cu}$, copper; Fe, iron; $\mathrm{Pb}$, lead; Li, lithium; Mn, manganese; Ni, nickel; $\mathrm{V}$, vanadium; $\mathrm{Zn}$, zinc; Sb, antimony; $\delta^{13} \mathrm{C}$, carbon stable isotopes; $\delta^{15} \mathrm{~N}$, nitrogen stable isotopes.

Abbreviation: SF, South Fork]

\begin{tabular}{lcccccccc}
\hline \multirow{2}{*}{$\begin{array}{c}\text { Fingerprint } \\
\text { property }\end{array}$} & \multicolumn{2}{c}{ Material } & \multicolumn{3}{c}{ Basin (SF and main stem) } & \multicolumn{2}{c}{ Reach } & \multicolumn{2}{c}{ Soil horizon } \\
\cline { 2 - 8 } & $\begin{array}{c}\text { Squared } \\
\text { sq-value }\end{array}$ & $\begin{array}{c}\text { Chi- } \\
\text { squared }\end{array}$ & p-value & $\begin{array}{c}\text { Chi- } \\
\text { squared }\end{array}$ & p-value & $\begin{array}{c}\text { Chi- } \\
\text { squared }\end{array}$ & p-value \\
\hline $\mathrm{Ca}$ & 7.64 & $\mathbf{0 . 0 2 2}$ & 8.950 & $\mathbf{0 . 0 0 3}$ & 13.62 & $\mathbf{0 . 0 0 9}$ & 4.096 & $\mathbf{0 . 0 4 3}$ \\
$\mathrm{Mg}$ & 6.11 & $\mathbf{0 . 0 4 7}$ & 0.062 & 0.803 & 7.3559 & 0.118 & 0.728 & 0.394 \\
$\mathrm{~K}$ & 13.6 & $\mathbf{0 . 0 0 1}$ & 3.528 & 0.063 & 13.053 & $\mathbf{0 . 0 1 1}$ & 0.438 & 0.508 \\
$\mathrm{Na}$ & 20.0 & $\mathbf{4 . 6 5} \times \mathbf{1 0}^{-5}$ & 23.113 & $\mathbf{0 . 0 0 0}$ & 26.618 & $\mathbf{0 . 0 0 0}$ & 1.160 & 0.281 \\
$\mathrm{C}$ & 7.83 & $\mathbf{0 . 0 2 0}$ & 19.917 & $\mathbf{0 . 0 0 0}$ & 17.866 & $\mathbf{0 . 0 0 1}$ & 6.615 & $\mathbf{0 . 0 1 0}$ \\
$\mathrm{Si}$ & 1.32 & 0.516 & 4.722 & $\mathbf{0 . 0 3 0}$ & 23.592 & $\mathbf{0 . 0 0 0}$ & 0.662 & 0.416 \\
$\mathrm{TN}$ & 7.26 & $\mathbf{0 . 0 2 7}$ & 16.529 & $\mathbf{0 . 0 0 0}$ & 16.247 & $\mathbf{0 . 0 0 3}$ & 7.332 & $\mathbf{0 . 0 0 7}$ \\
$\mathrm{P}$ & 20.9 & $\mathbf{2 . 9 5} \times \mathbf{1 0}^{-5}$ & 0.046 & 0.830 & 17.324 & $\mathbf{0 . 0 0 2}$ & 6.293 & $\mathbf{0 . 0 1 2}$ \\
$\mathrm{Al}$ & 8.96 & $\mathbf{0 . 0 1 1}$ & 27.04 & $\mathbf{0 . 0 0 0}$ & 32.679 & $\mathbf{0 . 0 0 0}$ & 0.544 & 0.461 \\
$\mathrm{Ba}$ & 6.31 & $\mathbf{0 . 0 4 3}$ & 0.003 & 0.957 & 21.318 & $\mathbf{0 . 0 0 0}$ & 2.966 & 0.085 \\
$\mathrm{Be}$ & 12.0 & $\mathbf{0 . 0 0 2}$ & 5.30 & $\mathbf{0 . 0 2 1}$ & 26.895 & $\mathbf{0 . 0 0 0}$ & 0.052 & 0.819 \\
$\mathrm{Cr}$ & 2.42 & 0.298 & 0.223 & 0.636 & 6.7382 & 0.150 & 0.207 & 0.649 \\
$\mathrm{Co}$ & 23.3 & $\mathbf{8 . 6 5} \times \mathbf{1 0}^{-6}$ & 0.656 & 0.418 & 12.65 & $\mathbf{0 . 0 1 3}$ & 3.719 & 0.054 \\
$\mathrm{Cu}$ & 19.1 & $\mathbf{7 . 1 0} \times \mathbf{1 0}^{-5}$ & 21.8 & $\mathbf{0 . 0 0 0}$ & 26.427 & $\mathbf{0 . 0 0 0}$ & 0.023 & 0.880 \\
$\mathrm{Fe}$ & 8.40 & $\mathbf{0 . 0 1 5}$ & 1.65 & 0.199 & 7.7225 & 0.102 & 0.518 & 0.472 \\
$\mathrm{~Pb}$ & 9.49 & $\mathbf{0 . 0 0 9}$ & 0.357 & 0.550 & 12.682 & $\mathbf{0 . 0 1 3}$ & 0.001 & 0.970 \\
$\mathrm{Li}$ & 8.51 & $\mathbf{0 . 0 1 4}$ & 16.9 & $\mathbf{0 . 0 0 0}$ & 18.674 & $\mathbf{0 . 0 0 1}$ & 0.107 & 0.744 \\
$\mathrm{Mn}$ & 20.8 & $\mathbf{3 . 0 0} \times \mathbf{1 0}^{-5}$ & 6.22 & $\mathbf{0 . 0 1 3}$ & 14.892 & $\mathbf{0 . 0 0 5}$ & 2.522 & 0.112 \\
$\mathrm{Ni}$ & 12.6 & $\mathbf{0 . 0 0 2}$ & 15.5 & $\mathbf{0 . 0 0 0}$ & 20.167 & $\mathbf{0 . 0 0 0}$ & 0.116 & 0.733 \\
$\mathrm{~V}$ & 10.9 & $\mathbf{0 . 0 0 4}$ & 3.98 & $\mathbf{0 . 0 4 6}$ & 14.572 & $\mathbf{0 . 0 0 6}$ & 1.377 & 0.241 \\
$\mathrm{Zn}$ & 20.5 & $\mathbf{3 . 6 0} \times \mathbf{1 0}^{-5}$ & 2.66 & 0.103 & 19.736 & $\mathbf{0 . 0 0 1}$ & 1.606 & 0.205 \\
$\mathrm{Sb}$ & 23.7 & $\mathbf{7 . 2 4} \times \mathbf{1 0}^{-6}$ & 0.572 & 0.449 & 12.776 & $\mathbf{0 . 0 1 2}$ & 4.088 & $\mathbf{0 . 0 4 3}$ \\
$\delta^{13} \mathrm{C}$ & 10.1 & $\mathbf{0 . 0 0 6}$ & 9.10 & $\mathbf{0 . 0 0 3}$ & 25.567 & $\mathbf{0 . 0 0 0}$ & 0.060 & 0.806 \\
$\delta^{15} \mathrm{~N}$ & 11.0 & $\mathbf{0 . 0 0 4}$ & 36.6 & $\mathbf{0 . 0 0 0}$ & 35.745 & $\mathbf{0 . 0 0 0}$ & 2.576 & 0.109 \\
\hline & & & & & & &
\end{tabular}

Multivariate discriminant analysis was not used to evaluate the five fingerprint properties used to differentiate soil horizons owing to the small number of significant results from the Kruskal-Wallis H-test. When the multivariate-discriminant analysis was applied to the source material data subset (those fingerprint properties that could be used to distinguish between samples) for material, basin, and reach, only three fingerprint properties were selected as the optimum combination for differentiating the individual sources in the material category (table 8). They were, in order of explanatory value, $\mathrm{Sb}, \mathrm{Cu}$, and $\mathrm{Mn}$. This composite fingerprint was able to correctly classify $66.7,36.4$, and 89.2 percent of the bed, levee and bank material, respectively (table 9). 
In the basin category, the composite fingerprint of $\delta^{15} \mathrm{~N}, \mathrm{Al}, \mathrm{Si}$, and $\mathrm{V}$ was able to correctly classify between the SF and main stem 100 percent of the time. In the reach category, the combination of $\delta^{15} \mathrm{~N}, \mathrm{Zn}, \mathrm{Al}, \mathrm{Be}, \delta^{13} \mathrm{C}, \mathrm{V}, \mathrm{Si}, \mathrm{P}, \mathrm{Co}, \mathrm{Na}$, and Li correctly classified reaches Main Stem A, Main Stem B, Main Stem C, NF, and SF 100, 92.9, 80, 100, and 100 percent of the time, respectively (table 9).

Table 8. Wilks' lambda test results for select fingerprint properties by material, basin, and reach categories, in the study area, Sprague River Basin, south-central Oregon.

[Fingerprint property: $\mathrm{Sb}$, antimony; $\mathrm{Cu}$, copper; $\mathrm{Mn}$, manganese; $\delta^{15} \mathrm{~N}$, nitrogen stable isotopes; $\mathrm{Al}$, aluminum; $\mathrm{Si}$, silicon; V, vanadium; Zn, zinc; Be, beryllium; $\delta^{13} \mathrm{C}$, carbon stable isotopes; $\mathrm{P}$, phosphorus; Co, cobalt; $\mathrm{Na}$, sodium; Li, lithium]

\begin{tabular}{lccccc}
\hline $\begin{array}{c}\text { Fingerprint } \\
\text { property }\end{array}$ & Wilks' lambda & $\begin{array}{c}\text { F-statistic } \\
\text { overall }\end{array}$ & $\begin{array}{c}\text { p-value } \\
\text { overall }\end{array}$ & $\begin{array}{c}\text { F-statistics } \\
\text { difference }\end{array}$ & $\begin{array}{c}\text { p-value } \\
\text { difference }\end{array}$ \\
\hline \multicolumn{5}{c}{ Material (bank, bed, levee) } \\
\hline $\mathrm{Sb}$ & 0.437 & 36.7 & $5.609 \mathrm{E}-11$ & 36.7 & $5.61 \mathrm{E}-11$ \\
$\mathrm{Cu}$ & 0.341 & 19.9 & $2.072 \mathrm{E}-12$ & 7.83 & $9.92 \mathrm{E}-04$ \\
$\mathrm{Mn}$ & 0.295 & 15.4 & $9.459 \mathrm{E}-13$ & 4.28 & $1.86 \mathrm{E}-02$ \\
\hline \multicolumn{5}{c}{ Basin (South Fork, main stem) } \\
\hline $\mathrm{d}^{15} \mathrm{~N}$ & 0.452 & 61.9 & $2.33 \mathrm{E}-10$ \\
$\mathrm{Al}$ & 0.283 & 63.3 & $2.01 \mathrm{E}-14$ & 61.9 & $2.33 \mathrm{E}-10$ \\
$\mathrm{Si}$ & 0.184 & 72.6 & $4.77 \mathrm{E}-18$ & 26.7 & $1.46 \mathrm{E}-06$ \\
$\mathrm{~V}$ & 0.107 & 100 & $1.14 \mathrm{E}-22$ & 3.6 .4 & $3.79 \mathrm{E}-06$ \\
\hline \multicolumn{5}{c}{ Reach (A, B, C, South Fork, North Fork) } \\
\hline $\mathrm{d}^{15} \mathrm{~N}$ & 0.374 & 23.0 & $3.19 \mathrm{E}-11$ & 23.0 & $3.19 \mathrm{E}-11$ \\
$\mathrm{Zn}$ & 0.179 & 18.4 & $3.76 \mathrm{E}-17$ & 14.7 & $3.06 \mathrm{E}-08$ \\
$\mathrm{Al}$ & 0.091 & 17.3 & $2.77 \mathrm{E}-22$ & 12.9 & $1.93 \mathrm{E}-07$ \\
$\mathrm{Be}$ & 0.043 & 17.9 & $6.99 \mathrm{E}-28$ & 14.2 & $6.29 \mathrm{E}-08$ \\
$\mathrm{~d}^{13} \mathrm{C}$ & 0.024 & 17.7 & $8.56 \mathrm{E}-32$ & 10.4 & $2.99 \mathrm{E}-06$ \\
$\mathrm{~V}$ & 0.015 & 17.1 & $2.79 \mathrm{E}-34$ & 7.51 & $7.78 \mathrm{E}-05$ \\
$\mathrm{Si}$ & 0.009 & 17.0 & $6.66 \mathrm{E}-37$ & 7.80 & $5.76 \mathrm{E}-05$ \\
$\mathrm{P}$ & 0.006 & 16.9 & $6.72 \mathrm{E}-39$ & 6.64 & $2.35 \mathrm{E}-04$ \\
$\mathrm{Co}$ & 0.004 & 17.2 & $3.22 \mathrm{E}-41$ & 7.30 & $1.12 \mathrm{E}-04$ \\
$\mathrm{Na}$ & 0.003 & 16.5 & $1.95 \mathrm{E}-41$ & 3.64 & $1.16 \mathrm{E}-02$ \\
$\mathrm{Li}$ & 0.002 & 15.7 & $3.07 \mathrm{E}-41$ & 2.97 & $2.92 \mathrm{E}-02$ \\
\hline
\end{tabular}


Table 9. Reclassification of fitness test results.

\begin{tabular}{|c|c|c|c|c|c|}
\hline MATERIAL & Bed & Levee & Bank & & \\
\hline Percent classified correctly & 66.7 & 36.4 & 89.2 & & \\
\hline BASIN & South Fork & Main Stem & & & \\
\hline Percent classified correctly & 100 & 100 & & & \\
\hline REACH & $A$ & B & C & North Fork & South Fork \\
\hline Percent classified correctly & 100 & 92.9 & 80 & 100 & 100 \\
\hline
\end{tabular}

\section{Discussion}

The composite fingerprints that differentiate multiple source area categories for the sites in this study can correctly classify sources 36.4-100 percent of the time (table 9). The categories with the highest correct classification percentages and the composite fingerprint with the most analytes were based on location; basin and reach, respectively. These results suggest that fingerprint properties could be used to differentiate basins and reaches, but additional sampling to increase the sample size, especially in the North Fork Sprague River Basin, would confirm these results. The composite fingerprint of $\delta^{15} \mathrm{~N}, \mathrm{Al}, \mathrm{Si}$, and $\mathrm{V}$ that classified the $\mathrm{SF}$ and mainstem basins 100 percent of the time suggests a unique signature of the SF compared to the mainstem Sprague River, which could be explained by land alterations in the SF, described by a high density of flow manipulation structures compared to other reaches in the Sprague River (O'Connor and others, 2015). Subdividing the basins into reaches resulted in a larger number of analytes (11) within the composite fingerprint compared to basin and material categories (four and three analytes, respectively) that could be used to differentiate sediment samples. This is likely because the sites represented in reach A were collected from mapped soil units different from the Klamath-Ontko-Dilman complex, which was the soil unit sampled at the sites in the other four reach categories (reach B, reach C, and North and South Forks). This indicates that the Woodcock gravelly medial loam and Maset coarse sandy loam have distinct signatures from the Klamath-Ontko-Dilman complex and indicates a high degree of spatial variability of sediment characteristics within the main-stem Sprague River in particular, even within the same mapped soil unit. The composite fingerprint for the reach category highlights the need for large spatial distribution of sites to adequately characterize changes in bank, bed, and levee sediment in a large basin such as the Sprague River Basin.

The lowest correct classification percent was based on material (bank, bed, levee). This result is not surprising given that, in the Sprague River Valley, most sediments are floodplain silts, sands and clays (O'Connor and others, 2015). They may have been reworked or anthropogenically modified, but they remain floodplain-derived sediments. The overall lowest classification percentage was for levees (36.4 percent), which historical references have shown were derived from excavated channels within the floodplain (O'Connor and others, 2015), but could also have included fill material from different areas within the basin (Dani Watson, Oregon Water Resources Department, oral commun., July 26, 2019). The unknown source of material from the levees and the fact that they were artificially constructed and, therefore, would not represent a soil formed naturally in place could have affected the low classification rate. In this study, the location of the sediment and the basin or stream reach from where it was collected 
has a greater influence on the fingerprint properties than source material (bank, bed, levee), which likely is owing to geology, localized land use, variability of soil characteristics within the same mapped soil unit, and variability in soil geochemistry between different soil units.

The pollutant of concern in the Sprague River Basin is $\mathrm{P}$, and our results show that $\mathrm{P}$ in sediment samples ranged from 20 to $1,000 \mathrm{mg} / \mathrm{kg}(\mathrm{n}=62)$, with the highest concentrations occurring in two bed material samples in the North Fork Sprague River Basin (1,000 and 430 $\mathrm{mg} / \mathrm{kg}$ P), and one A horizon sample from a bank in the South Fork Sprague River Basin (460 $\mathrm{mg} / \mathrm{kg}$ P). Soils in the Sprague River Basin are expected have high concentrations of P because of their volcanic origin from the eruption of Mount Mazama (Crater Lake) about 6,800 years ago (Graham and others, 2005). Although the results suggest that bank and bed sediments in these localized areas contain high concentrations of $\mathrm{P}$, additional sampling is required to confirm if the concentrations are consistently high in these areas of the Sprague River Basin.

\section{Future Sprague River Sediment Fingerprinting Studies}

This proof-of-concept study indicates that there are unique combinations of fingerprint properties (composite fingerprints) in bank, bed, and levee sediment from the Sprague River Basin that can be used to differentiate between a variety of sediment source categories. Additional sampling would be required to more adequately characterize the North Fork Sprague River, given that only seven samples were collected from that basin. Following an additional sampling effort, the next logical progression of this pilot study would be to use these fingerprint properties to quantify the relative contribution of each source category to sedimentation downstream. More details about the steps involved in a more comprehensive study are available in Walling and Collins (2008) and Gellis and Walling (2011). The next steps generally would be:

1. Take additional samples of reaches to provide a more robust dataset, with a focus on the NF Sprague River Basin where few samples were collected, and those areas in the NF and SF where P concentrations were high.

2. Refine unique fingerprint properties to differentiate between sources using the statistical procedures outlined in this report.

3. Collect suspended-sediment samples from predefined locations in the Sprague River Basin using either passive samplers or isokinetic samplers during storm events to determine fingerprint properties for sediment in transport. Analyze the sediment in the samples for the same fingerprint properties evaluated in this report.

4. Calibrate and run publicly available un-mixing models such as the Sediment Source Assessment tool (Sed_SAT) (Gorman Sanisaca and others, 2017) to determine the relative contribution of various sediment sources to sediment and P loads in the Sprague River Basin.

An understanding of sediment sources and associated P loading in the Sprague River Basin is important for improving water quality and hypereutrophic conditions in UKL, which is the primary habitat for two federally endangered suckers. The TMDL requirement of a 40 percent reduction in external $\mathrm{P}$ loads is intended to limit cyanobacterial blooms and thereby improve lake water-quality conditions for those protected species. Sediment fingerprinting is a promising technique that can determine the sources of sediment and associated $\mathrm{P}$ in the Sprague River Basin. A comprehensive study would facilitate prioritization for restoration efforts designed to reduce external loads and improve water-quality conditions in UKL. 


\section{Acknowledgments}

Chauncey Anderson of the U.S. Geological Survey Oregon Water Science Center wrote a proposal for the National Science Foundation Graduate Research Internship Program, which was awarded and provided funding for Julia Kelson, who conducted background research, organized field logistics and sample design, and sieved many samples at the University of Washington. Access to field sites was provided graciously by numerous landowners in the Sprague River Basin. Introductions to these landowners was facilitated by Sue Mattenberger, formerly of the U.S. Fish and Wildlife Service, and Chrysten Lambert and Nell Scott, of Trout Unlimited.

\section{References Cited}

American Public Health Association, 2017, 4500-P PHOSPHORUS, in Standard methods for the examination of water and wastewater (23d ed.): American Public Health Association, p. 4156-4-172.

Boyd M., Kirk S., Wiltsey M., and Kasper B., 2002, Upper Klamath Lake drainage total maximum daily load (TMDL) and water quality management plan (WQMP): Portland, State of Oregon Department of Environmental Quality, 204 p.

British Columbia Ministry of Environment, 2001, Composite samples-A guide for regulators and project managers on the use of composite samples: British Columbia Ministry of Environment Guidance Document No. 12-10, 4, p, accessed May 6, 2019, at https://www2.gov.bc.ca/assets/gov/environment/air-land-water/siteremediation/docs/guidance-documents/gd10.pdf.

Cahoon, J.S., 1985, Soil Survey of Klamath County, Oregon-Southern part: U.S. Department of Agriculture Soil Conservation Service and Oregon State University Agricultural Experiment Station, 106 map sheets, 269 p.

Chattopadhyay, S., Agouridis, C.T. and Fox, J.F., 2016, Sediment fingerprinting: Lexington, University of Kentucky Agriculture and Natural Resources Publications, Paper 86, 4 p.

Collins, A.L., Pulley, S., Foster, I.D.L., Gellis, A., Porto, P., and Horowitz, A.J., 2017, Sediment source fingerprinting as an aid to catchment management-A review of the current state of knowledge and a methodological decision-tree for end-users: Journal of Environmental Management, v. 194, p. 86-108, https://doi.org/10.1016/j.jenvman.2016.09.075.

Collins, A.L., and Walling, D.E., 2002, Selecting fingerprint properties for discriminating potential suspended sediment sources in river basins: Journal of Hydrology, v. 261, p. $218-$ 244, https://doi.org/10.1016/S0022-1694(02)00011-2.

Collins, A.L., Zhang, Y., McChesney, D., Walling, D.E., Haley, S.M., and Smith, P., 2012, Sediment source tracing in a lowland agricultural catchment in southern England using a modified procedure combining statistical analysis and numerical modelling: Science of the Total Environment, v. 414, p. 301-317, https://doi.org/10.1016/j.scitotenv.2011.10.062.

Davis, C.M., and Fox, J.F., 2009, Sediment fingerprinting-Review of the method and future Improvements for Allocating nonpoint Source Pollution: Journal of Environmental Engineering, v. 135, p. 490-504, https://doi.org/10.1061/(ASCE)0733-9372(2009)135:7(490). Du, P.F., and Walling, D.E., 2017, Fingerprinting surficial sediment sources-Exploring some potential problems associated with the spatial variability of source material properties: Journal of Environmental Management, v. 194, p. 4-15, https://doi.org/10.1016/j.jenvman.2016.05.066. 
Eldridge, D.B., Caldwell Eldridge, S.L., Schenk, L.N., Tanner, D.Q., and Wood, T.M., 2012, Water-Quality Data from Upper Klamath and Agency Lakes, Oregon, 2009-10: U.S. Geological Survey Open-File Report 2012-1142, 32 p., https://doi.org/10.3133/ofr20121142.

Gellis, A., Fitzpatrick, F. and Schubauer-Berigan, J., 2016, A manual to identify sources of fluvial sediment: U.S. Environmental Protection Agency Report EPA/600/R-16/210, 106 p., https://nepis.epa.gov/Exe/ZyPDF.cgi/P100QVM1.PDF?Dockey=P100QVM1.PDF.

Gellis, A.C., Myers, M.K., Noe, G.B., Hupp, C.R., Schenk, E.R., and Myers, L., 2017, Storms, channel changes, and a sediment budget for an urban-suburban stream, Difficult Run, Virginia, USA: Geomorphology, v. 278, p. 128-148, https://doi.org/10.1016/j.geomorph.2016.10.031.

Gellis, A.C., and Walling, D.E., 2011, Sediment source fingerprinting (tracing) and sediment budgets as tools in targeting river and watershed restoration programs: Stream Restoration in Dynamic Fluvial Systems-Scientific Approaches, Analyses, and Tools, Geophysical Monograph Series 194, American Geophysical Union, p. 263-291.

Gorman Sanisaca, L.E., Gellis, A.C. and Lorenz, D.L., 2017, Determining the sources of finegrained sediment using the Sediment Source Assessment Tool (Sed_SAT): U.S. Geological Survey Open-File Report 2017-1062, 104 p., https://doi.org/10.3133/ofr20171062.

Graham, S.A., Craft, C.B., McCormick, P.V., and Aldous, A., 2005, Forms and accumulation of soil $\mathrm{P}$ in natural and recently restored peatlands - Upper Klamath Lake, Oregon, USA:

Wetlands, v. 25, no. 3, p. 594-606, https://doi.org/10.1672/02775212(2005)025[0594:FAAOSP]2.0.CO;2.

Graham Mathews and Associates, 2007, Sprague River watershed-Streamflow, sediment transport, and a preliminary sediment budget, WY2004-2006: Technical Report to the Klamath Tribes Natural Resources Department, 18 p. plus appendices.

Gross, J., and Ligges, U., 2015, Nortest-Tests for normality, R package version 1.0-4: The Comprehensive R Archive Network web page, https://CRAN.R-project.org/package=nortest.

Haddadchi, A., Ryder, D.S., Evrard, O., and Olley, J., 2013, Sediment fingerprinting in fluvial systems - Review of tracers, sediment sources and mixing models: International Journal of Sediment Research, v. 28, p. 560-578, https://doi.org/10.1016/S1001-6279(14)60013-5.

Koiter, A.J., Owens, P.N., Petticrew, E.L., and Lobb, D.A., 2013, The behavioural characteristics of sediment properties and their implications for sediment fingerprinting as an approach for identifying sediment sources in river basins: Earth-Science Reviews, v. 125, p. 24-42, https://doi.org/10.1016/j.earscirev.2013.05.009.

Mukundan, R., Walling, D.E., Gellis, A.C., Slattery, M.C., and Radcliffe, D.E., 2012, Sediment source fingerprinting - Transforming from a research tool to a management tool: Journal of the American Water Resources Association, v. 48, p. 1241-1257, https://doi.org/10.1111/j.17521688.2012.00685.x.

Newfields River Basin Services, 2012, Evaluating stream restoration projects in the Sprague River Basin: Prepared for Klamath Watershed Partnership, Technical Report, 240 p.

O’Connor, J.E., McDowell, P.F., Lind, P., Rasmussen, C.G., and Keith, M.K., 2015, Geomorphology and flood-plain vegetation of the Sprague and lower Sycan Rivers, Klamath Basin, Oregon: U.S. Geological Survey Scientific Investigations Report 2014-5223, 122 p. plus 1 pl., accessed May 2, 2017, at http://dx.doi.org/10.3133/sir20145223.

Oregon Department of Agriculture, 2017, Klamath headwaters agricultural water quality management area plan: Salem, Oregon Department of Agriculture, 73 p., https://www.oregon.gov/ODA/programs/NaturalResources/AgWQ/Pages/AgWQPlans.aspx. 
R Core Team, 2017, R-A language and environment for statistical computing: Vienna, Austria, R Foundation for Statistical Computing, https:/www.R-project.org/.

Résvész, K., Qi, H., and Coplen, T.B., 2012, Determination of the $\delta^{15} \mathrm{~N}$ and ${ }^{813} \mathrm{C}$ of total nitrogen and carbon in solids; RSIL lab code 1832, chap. 5 of Stable isotope-ratio methods, sec. C of Révész, Kinga, and Coplen, T.B. eds., Methods of the Reston Stable Isotope Laboratory (slightly revised from version 1.1 released in 2007): U.S. Geological Survey Techniques and Methods, book 10, 31 p., https://pubs.usgs.gov/tm/2006/tm10c5/.

Rouhe, A.C., and Rueter, J.G., 2018, Reducing surface accumulation of Aphanizomenon flosaquae using wetland water to increase cellular turgor pressure and interfere with buoyancy regulation: Lake and Reservoir Management, v. p. 426-446, https://doi.org/10.1080/10402381.2018.1466011.

Schenk, L.N., Anderson, C.W., Diaz, P., and Stewart, M.A., 2016, Evaluating external nutrient and suspended-sediment loads to Upper Klamath Lake, Oregon, using surrogate regressions with real-time turbidity and acoustic backscatter data: U.S. Geological Survey Scientific Investigations Report 2016-5167, 46 p., accessed April 20, 2017, at http://pubs.er.usgs.gov/publication/sir20165167.

Stumm, W., and Morgan, J.J., 1981, Aquatic chemistry-An introduction emphasizing chemical equilibria in natural waters (2d ed.): New York, Wiley, $796 \mathrm{p}$.

U.S. Environmental Protection Agency, 2000, Method 6010C, Inductively coupled plasmaatomic emission spectrometry: U.S. Environmental Protection Agency, 30 p., https:/www.epa.gov/sites/production/files/2015-07/documents/epa-6010c.pdf.

U.S. Fish and Wildlife Service, 1988, Endangered and threatened wildlife and plantsDetermination of endangered status for the shortnose sucker and Lost River sucker: Federal Register, v. 53, p. 27130-27134.

Venables, W.N., and Ripley, B.D., 2002, Modern applied statistics with S (4th ed.): New York, Springer, ISBN 0-387-95457-0, 504 p.

Walker, J.D., Kann, J., and Walker, W., 2015, Spatial and temporal nutrient loading dynamics in the Sprague River Basin, Oregon: Technical Report to the Klamath Tribes Natural Resources Department 96 p.

Walker, W., Walker, J., and Kann, J., 2012, Evaluation of water and nutrient balances for the Upper Klamath Lake Basin in water years 1992-2010: Technical Report to the Klamath Tribes Natural Resources Department, p. 50 plus appendixes.

Walling, D. E., and Collins, A.L., 2008, The catchment sediment budget as a management tool: Environmental Science Policy, no. 11, v. 2, p. 136-143. Walling, D.E., 2013, The evolution of sediment source fingerprinting investigations in fluvial systems: Journal of Soils and Sediments, v. 13, no. 10, p. 1658-1675, https://link.springer.com/content/pdf/10.1007\%2Fs11368-013-0767-2.pdf.

Watson, C.C., Biedenharn, D.S., and Bledsoe, B.R., 2002, Use of incised channel evolution models in understanding rehabilitation alternatives: Journal of the American Water Resources Association, v. 38, p. 151-160., https://doi.org/10.1111/j.1752-1688.2002.tb01542.x.

Weihs, C., Ligges, U., Luebke, K., and Raabe, N., 2005, klaR analyzing German business cycles, in Baier, D., Decker, R., and Schmidt-Thieme, L., eds., Data analysis and decision support: Berlin, Springer-Verlag, p. 335-343.

Wherry, S.A., Wood, T.M., and Anderson, C.W., 2015, Revision and proposed modification for a total maximum daily load model for Upper Klamath Lake, Oregon: U.S. Geological Survey Scientific Investigations Report 2015-5041, 55 p., https://doi.org/10.3133/sir20155041. 
Wood, T.M., Hoilman, G.R. and Lindenberg, M.K., 2006, Water-quality conditions in Upper Klamath Lake, Oregon, 2002-04: U.S. Geological Survey Scientific Investigations Report 2006-5209, 52 p https://doi.org/10.3133/sir20065209.

Wood, T.M., Wherry, S.A., Carter, J.L., Kuwabara, J.S., Simon, N.S., and Rounds, S.A., 2013, Technical evaluation of a total maximum daily load model for Upper Klamath and Agency Lakes, Oregon: U.S. Geological Survey Open-File Report 2013-1262, 75 p., https://pubs.usgs.gov/of/2013/1262/. 


\section{Appendix 1. Analytical Results and Site Characteristics}

Appendix 1 is an Excel ${ }^{\circledR}$ file available for download at https://doi.org/10.3133/ofr20191120. 

Publishing support provided by the U.S. Geological Survey Science Publishing Network, Tacoma Publishing Service Center

For more information concerning the research in this report, contact the Director, Oregon Water Science Center

U.S. Geological Survey

2130 SW 5th Avenue

Portland, Oregon 97201

https://www.usgs.gov/centers/or-water 


\section{$\frac{2}{2}$}

